\title{
The improvement of Self Immunity, Mental and Psychosocial Health to Prevent Covid-19 Infection in Elders in Surakarta Indonesia
}

\author{
Argyo Demartoto*, Siti Zunariyah, Sri Hilmi Pujihartati \\ Department of Sociology, Sebelas Maret University, Surakarta, Indonesia
}

\begin{abstract}
Elder group is the one with the risk of being infected with Coronavirus Disease 19 (Covid-19). It is very important to prevent Covid19 transmission with any attempt, particularly in elders. This research aimed to help explain the importance of maintaining immunity and preventing Covid-19 transmission to elders in order to be alerted to Covid-19 in Surakarta Indonesia. This qualitative research with explorative approach employed purposive sampling technique. Unit of analysis consisted of elders in many areas in Surakarta, Chief Executive of Covid-19 Management Acceleration Task force of Surakarta City, pulmonologist and nurses in Dr. Moewardi Surakarta Hospital, Chairperson of Surakarta City's Health Office (DKK), Head of Disease Control and Environmental Health Division of Surakarta Health Office, and Chairperson of Surakarta City's Social Office. Data collection was conducted through observation, in-depth interview, and documentation, and then method and data source triangulations. Data analysis was conducted using an interactive model of analysis with Parsons' system theory. The result of research showed that the Covid-19 prevention in elders in Surakarta was conducted through improving their physical immunity, nursing care for elders, nursing care for family, and preventing physical, and mental and psychosocial health problems in elders.
\end{abstract}

Keywords. elders, body immunity, Covid-19

\section{Introduction}

The transmission of Coronavirus Disease 19 (Covid-19) occurred and was reported for the first time by China government in Wuhan on December 2019. This virus infection case increases rapidly and transmits throughout world, including Indonesia. Covid-19 can infect any age classes. It is associated with body immunity system, so that the lower the immunity system, the riskier the individual. Considering CDC released by Statista, mortality rate increases in line with patient's age. The first case was found in Indonesia and announced on March 2, 2020, and the number increased over times. On March 11, 2020, WHO announced

*Corresponding author: argyodemartoto fisip@,staff.uns.ac.id 
Covid-19 as pandemic, after the virus coming from Wuhan, China, transmits to at least 188 countries [1], 8 (eight) of which) reported more than 150,000 infected cases [2]. They are United States of America, Italia, Iran, South Korea, France, Spain, and German. Case fatality rate is estimated to be $1-3 \%$, with the highest mortality rate in persons aged $\geq 85$ years of $10 \%-27 \%$, followed with $3 \%-11 \%$ in persons aged $65-84$ years, $1 \%-3 \%$ in persons aged 55 64 years, $<1 \%$ in persons aged $20-54$ years, and none in persons aged $\leq 19$ years [1].

Data collected suggests that this virus is found to infect elders. Out of total 44,672 cases in mainland China per February 11, 2020, 14.8\% occurs in persons aged $\geq 80$. Meanwhile, citing Quartz on March 1, 2020, the data existing in UK and China mention 41 deaths due to this virus, 39 of which occurs in patients aged $\geq 50$. Most of victims are elders. Citing the President of Italian Health High Institution (Silviro Brusaferro), in The Guardian, the life tolls of Corona Virus in Italia are people aged 80.3 years on average. Based on update data of corona released by Covid-19 Management Acceleration Task Force, 21.745 positive dead patients (per May 7, 2020) are $\geq 60$ years old in Indonesia. About 17,70 percent of death cases due to Covid-19 occurs in persons aged $\geq 60$ in Indonesia. This age group is affected most severely by corona virus infection. In addition, they have poor medical record, from hypertension, heart disease, to cancer. Simply, elders are the population group most vulnerable to Corona virus [3].

Vulnerable-to-Covid-19 people group is the one with risk of or sensitivity to Covid-19 infection, due to the current condition. This vulnerable group consists of elders, persons with comorbid or comorbidity, pregnant/postpartum/lactating women, children, people with mental disorder, and health workers [2]. Elders are those aged $\geq 60$. Elders are the age classification of human beings who have faced the last stage of life phase. This elderclassified group generally undertakes a life process called Ageing Process [2]. It is included in Republic of Indonesia's Law Number 43 of 2004 about the Implementation of the Attempt of Improving Elders' Social Welfare and Minister of Health's Regulation Number 57 of 2015 about the Organization of Elder Healthcare Service in Public Health Centre.

Ageing process is a phase in an individual's life cycle with the following characteristics: degraded function of body organ such as weaker physical, emotional, psychological condition social ability, leading to reduced body immunity, so that an elder becomes vulnerable to a variety of death-inducing disease attacks such as respiratory system, cardiac and blood vessel, digestion, endocrine, and etc. It is because, the older the individual, the more is the change occurring in cellular structure, tissue, and organ system functions. The change generally leads to physical and psychical health deterioration that in turn will affect the elders' ability of doing daily living activities [6, 7].

Ageing process results in degraded biological functions of body including organ function deterioration entirely and progressively, and thereby increases the vulnerability to environmental change and risk of being infected with disease and death. Ageing is not a process occurring homogeneously. But the ageing process occurring in all of elder human body organs indicates the mechanism at different times affected by such factors as genetics, daily living habit, and surrounding environment exposition [6, 8]. Ageing process will keep occurring and resulting in a variety of morphological change affecting the function of respiratory system. Respiratory system in elders indicates structural and functional degradation, thereby respiratory work increases compared with that in young age. It is associated with the degraded ability when developing other acute diseases like cardiac disorder, bacterial or virus infection, and obstructive respiratory tract $[7,9,10]$.

Elder group belongs to the one vulnerable to coronavirus disease-19 (Covid-19) transmission, along with those with comorbidity and smoker. Elders are vulnerable to a variety of bacterial and virus infection and disease, including Covid-19 [1]. Functional capacity of body organs, including elders' immunity, deteriorates due to ageing thereby vulnerable to any infection. Some body functions deteriorate with the older age: lost thymus 
gland, thinner skin, reduced mucous gland and other body organ functions [16]. In addition, elders' appetite decreases so that nutrition intake is unfulfilled. Such condition makes body's response not as quick and effective as that in young age $[17,18]$.

This group should be more alert, moreover those with comorbidity such as autoimmune, diabetes, hypertension, cancer, and cardiac disease [19, 20]. Additionally, multipathological elders or those developing a number of diseases, when infected with Covid-19, will develop health complication and serious risk. In addition to resulting in pulmonary impairment, Covid-19 infection can also deteriorate other body organs' functions, so that chronic diseases condition developed by patients will get worse and even result in death [1, 21]. Covid-19 prevention is a system consisting of a number of interrelated elements or components with one or some principles. It indicates the complexity of interdependence between parts, components, and process encircling the rule of recognizable relationship [11]. This article aims to improve elders' knowledge on Covid-19 prevention, thereby can improve their alertness independently to this virus infection transmission and expansion.

\section{Method}

This qualitative research with explorative approach took place in Surakarta, Indonesia. Informants were selected using purposive sampling technique adjusted with the research need and interest. The unit of analysis consisted of key informants including Chief Executive of Covid-19 Management Acceleration Task force of Surakarta City, pulmonologist and nurses in Dr. Moewardi Surakarta Hospital, Chairperson of Surakarta City's Health Office (DKK), and Head of Disease Control and Environmental Health Division of Surakarta Health Office; main informants including elders coming from many areas in Surakarta; and supporting informants including Chairperson of Social Office of Surakarta City.

Observation and in-depth interview were conducted on the group being the target of research to collect data on the importance of maintaining immunity to elders and how to avoid and to prevent Covid-19 infection, including documentation related to the object of research. Data validation was conducted using source and method triangulations. Data analysis was carried out using an interactive model of analysis consisting of three main components: data reduction, data display, and conclusion drawing [12]. Data analysis was conducted using Parsons' system theory.

\section{Result}

\subsection{Elders as vulnerable group}

Elders are individuals who have been 60 years old and more. Elders are the age group in human having entered into the last stage of life phase. Elders are the group experiencing ageing process, the life cycle characterized with degraded function of many body organs (degeneration), more vulnerability to comorbidity such as cardiovascular system, respiratory, gastrointestinal, and endocrine disorders. This condition occurs due to the change in cellular structure and function, tissue and organ system. The change occurring generally leads to physical, psychical, and psychosocial health deterioration in elders.

Surakarta Central Bureau of Statistic's data shows that the number of Surakarta populations is 517,887 people, with 58,905 people aged $\geq 60 ; 26,346$ males and 32,559 females. Generally, they live along with family, independently and in nursing home with health status of Covid-19-free, but some of them develop comorbidity such as diabetes, cardiac, pulmonary diseases, and etc. In the attempt of preventing Covid-19, Surakarta City's government establishes Executive Team of Covid-19 Management Acceleration Task Force 
of Surakarta City with any programs and activities. To protect elders from Covid-19, body immunity should be maintained. Body immunity can be created through eating nutritious healthy food, avoiding psychological stress, and doing sufficient physical exercise. Considering the Covid-19 guidance for elders, the elders' family should maintain healthy lifestyle through eating balanced nutritious food. If elders develop chronic disease, they should not discontinue their drug consumption and should have adequate drug stock at home, consult with reliable physician before consuming it in long term. Diabetic elders should check their blood tension and blood sugar level periodically and independently without getting out of home. Those using inhaler should use it as usual, contact the physician when they develop fever, and narrow breath. They should ask other family members buy their personal needs. They should maintain social and physical distancing at home by not shaking hand.

Elders are appealed to keep searching for Covid-19 information on how to access medical help, and where health facilities are accessible. For avoiding boredom, elders can do physical exercises such as light gymnastic, respiratory exercise, listening to favourite music, gardening or doing any other hobbies with social distancing principle. Help should be given to elders by considering whether or not there is elders homeless/living alone/poor/developing dementia or psychosocial disability. Elders with dementia should get understandable information and need support to prevent them from being stressed or worry. Elders with Covid-19 isolation should acquire actual information on the risk likely occurring and the curing probability. Prevention guidance is expected to be communicated patiently, clearly, and understandably. If elders living in nursing home develop the symptoms, they should isolate themselves independently through moving to personal room and designating special nurse to take care of them. In addition, elders with skill, experience, and power to be volunteers to respond to Covid-19 should be involved. Elders can give peer support, and support child caretaking to the neighbors quarantined (patients under observation).

\subsection{Improving elders' physical immunity}

During Covid-19 pandemic period, people in Surakarta attempt to safeguard their vulnerable family members, such as elders, by staying at home, maintaining their health, and ensuring that they consume their drug routinely, and keep social distancing with the sick young members. The health promotion attempt is conducted in vulnerable group (elders) by improving physical immunity and mental and psychosocial health in healthy elders. The improvement of physical immunity in elders is as same as that in healthy people or general society, but added with balanced food and beverage, high-protein and fibrous food such as vegetables and fruits, and multivitamin if necessary. Adequate warm water should be consumed according to the elders' body weight or at least 1.5-2 litres per day. Safe environment for elders is unsmooth (not-slippery) floor and stairs, bathroom with handle, toilet seat, bedroom located in the basement equipped with furniture not inhibiting elders' movement. Body movement through light such exercises as respiratory practice (yoga) and elder gymnastic for at least 30 minutes, adjusted with their ability. Physical examination should be conducted regularly in healthcare service facilities usually used (coordination with the public health nurses responsible for elders).

\subsection{Improving the Mental and Psychosocial Health Immunity of Elders}

Covid-19 pandemic has affected all Surakarta people, including elders. Nursing care given to elders is the nursing diagnosis regarding the preparedness for elder development to enable the elders to achieve the development stage task, the preparedness for giving positive experiences owned (generativity) and integrity, the meaning of life. The improvement of mental and psychosocial immunity in elders is conducted through nursing care for elders. It 
is carried out by discussing the development and the change occurring in elders, the meaning and the physical change, the meaning of life, and the change of mind, the meaning of social relationship and its change, and the meaning of spiritual experience and its experience, and supported with nursing care for the family.

\section{Discussion}

Elders' health system includes physical, mental, and psychosocial, that are interrelated and supports each other. Community life is like a system functionally integrated into equilibrium [11]. It is also true for the health system in the attempt of preventing elders from being infected with Covid-19. Therefore, elders, elders' family, community, and healthcare service provider as a health system should obligatorily improve self-immunity, mental and psychosocial health of elders to avoid them from Covid-19 infection.

Elder condition having experienced body function and immunity degeneration needs a right and tight attempt of preventing Covid-19 transmission. In addition, physical weakness of elders can make them dangerous, for they can transmit Covid-19 virus to others. For that reason, an attempt is required to prevent the transmission of Covid-19 to elders or from elders to others. The attempt of preventing physical problem taken in elders is as same as that in health person (OS) or people without symptoms (OTG), in addition to avoiding contact with child, child in law, and grandchild, particularly through not shaking hand and hugging, because others can likely transmit Covid-19 to elders. If the elders are sick not due to emergency condition (haemorrhage, severe breast pain, diarrhoea/vomit, poor appetite, high fever, consciousness decrease, narrow breath, falling down, and etc.), just call physician, nurse, and other health workers through telemedicine/telenursing/other online facilities, so that elders will keep staying at home. Save contact number of the proximate physician/nurse/health worker or those visited routinely by elders [13-15].

Listening to or watching news about Covid-19 can generate fear, anxiety, worry, and feeling of death threat against elders. Elders will see others more reluctantly, and be suspicious of others transmitting the virus to them. If this condition continues, it can generate emotion and negative thinking that can increase cortisol hormone production and lower immunity system in elders. This condition can make elders infected with Covid-19 more easily [22]. The prevention of mental and psychosocial health problems in elders are all preventive practices conducted against OS, people with monitoring (ODP), patients with supervision (PDP), in addition to remembering the joyful past when they are alone, along with family, and peer.

In the attempt of preventing Covid-19, the type of exercises performed should be adjusted with elders' age, sex, and disease history. Elders can perform physical exercise either individually or in group. The physical exercise recommended to elders is, among others, jogging because it is a physical activity safe to elders. Jogging, low-impact aerobics gymnastic, bicycling, and swimming are example of physical exercises that can be performed using telehealth method [23]. Physical exercises for elders can be conducted regularly $3-4$ times a week for 10-30 minutes, corresponding to the elders' health condition. There are three physical exercise tips for elders: moderate intensity to minimize injury risk, conducted routinely 3-4 times a week for not more than 30 minutes in initial duration, and varying exercises to prevent boredom [27].

It is confirmed by some studies finding that physical exercise benefiting the health considerably. This activity not only prevents and reduces the risk of many diseases, but clinically contributes to curing and recovery from disease. It is likely because physical exercise results in physiological change affecting body positively, as it improves cardiac function, smoothes blood flow, controlling blood sugar level, and improving muscular strength and body immunity. In addition to benefiting physically, physical exercise also 
contributes to mental and cognitive health [24-27]. Physical exercise can lower tension and fatigue, improve life motivation and a sense of achievement, improve happiness, and achieve better social life [28]. Through a synergy of improved body immunity, mental and psychosocial health in elders, the prevention of Covid-19 transmission in elders can run optimally.

\section{Conclusion}

In addition to be vulnerable to Covid-19 infection, elders can experience severer symptoms when they are infected with Covid-19, particularly those with severe disease history such as cardiac, pulmonary, and diabetic diseases. An attempt should be taken to ensure that elders obtain consciousness of personal protection, measures, and hand cleanliness requirement; avoid sharing personal stuffs; and applying recommended health protocol. Elders should be encouraged to wash hand frequently. The procedure of Covid-19 prevention in elders is generally as same as that in productive age, but it needs more caution and patience in practice, moreover in maintaining their health.

\section{References}

1. Centers for Disease Control and Prevention (CDC), Supplement: Community Containment Measures, Including Non Hospital Isolation and Quarantine, https://www.cdc.gov/sars/guidance/d-quarantine/app3.html (2020).

2. WHO, Infection prevention and control for the safe management of a dead body in the context of COVID-19: interim guidance 24 March 2020, https://apps.who.int/iris/handle/10665/331538 (2020)

3. CSSE, JHU, Coronavirus COVID-19 Global Cases by the Center for Systems Science and Engineering (CSSE) at Johns Hopkins University (JHU), https://coronavirus.jhu.edu/map.html (2020).

4. WHO, Ageing and health. Geneva 2018, https://www.who.int/news-room/factsheets/detail/ageing-and-health (2018).

5. WHO, Coronavirus disease 2019 (COVID-19) Situation Report 48, https://www.who.int/docs/default-source/coronaviruse/situation-reports/20200308sitrep-48-covid-19.pdf?sfvrsn=16f7ccef_4 (2020).

6. C. A. Cefalu, Theories and mechanisms of ageing, Clinics in geriatric medicine, 27(4), 491-506 (2011).

7. J. Lord, The Ageing Process and Healthy Ageing, Birmingham Policy Commission, 1-5 (2014).

8. M. Dziechciaz, R. Filip, Biological psychological and social determinants of old age: Bio-psycho-social aspects of human ageing. Annals of Agricultural and Environmental Medicine, 21(4), 835-838 (2014).

9. R. E. Tavares, M. C. P. D. Jesus, D. R. Machado, V. A. S. Braga, F. R. Tocantins, M. A. $\mathrm{B}$. Merighi, Healthy ageing from the perspective of the elderly: an integrative review. Revista Brasileira de Geriatria e Gerontologia, 20(6), 878-889 (2017).

10. K. Liu, W. Zhang, Y. Yang, J. Zhang, Y. Li, Y. Chen, Respiratory rehabilitation in elderly patients with COVID-19: A randomized controlled study, Complementary Therapies in Clinical Practice, 101166 (2020).

11. T. Parsons, The social system, Routledge, London (2013).

12. M. B. Miles, A. M. Huberman, J. Saldaña, Qualitative data analysis: A methods sourcebook, 3rd. ed, Sage Publications, Thousand Oaks, CA (2014). 
13. Direktorat Jenderal Pencegahan dan Pengendalian Penyakit (P2P) Kementerian Kesehatan Republik Indonesia, Pedoman Pencegahan dan Pengendalian Corona Virus Disease (COVID-19), Direktorat Jenderal Pencegahan dan Pengendalian Penyakit (P2P) Kementerian Kesehatan Republik Indonesia, Jakarta (2020).

14. Kementerian Kesehatan Republik Indonesia, Pedoman Dukungan Kesehatan Jiwa dan Psikososial Pada Pandemi COVID-19, Kementerian Kesehatan Republik Indonesia, Jakarta (2020).

15. R. Kunz, M. Minder, COVID-19 pandemic: palliative care for elderly and frail patients at home and in residential and nursing homes, Swiss Medical Weekly, 150(1314) (2020).

16. T. Zhu, Y. Wang, S. Zhou, N. Zhang, L. Xia, A Comparative Study of Chest Computed Tomography Features in Young and Older Adults With Corona Virus Disease (COVID19), Journal of Thoracic Imageing, p W97-W101 (2020).

17. J. E. Morley, B. Vellas, COVID-19 and Older Adults, Journal of Nutrition, Health \& Aging, 24(4), 364-365 (2020).

18. L. Wang, W. He, X. Yu, D. Hu, M. Bao, H. Liu, J. Zhou, H. Jiang, Coronavirus Disease 2019 in elderly patients: characteristics and prognostic factors based on 4-week followup, Journal of Infection, 4(6), P639-645 (2020).

19. A. J. Sinclair, A. H. Abdelhafiz, Age, frailty and diabetes-triple jeopardy for vulnerability to COVID-19 infection. EClinicalMedicine (2020).

20. J. Zhang, W. Wu, X. Zhao, W. Zhang, Recommended psychological crisis intervention response to the 2019 novel coronavirus pneumonia outbreak in China: a model of West China Hospital, Precision Clinical Medicine, 3(1), 3-8 (2020).

21. M. Myrstad, A. H. Ranhoff, Acutely ill older people in the corona era, Tidsskrift for Den norske legeforening, https://idsskriftet.no/en/2020/03/debatt/acutely-ill-older-peoplecorona-era (2020).

22. Y. Yang, W. Li, Q. Zhang, L. Zhang, T. Cheung, Y. T. Xiang, Mental health services for older adults in China during the COVID-19 outbreak, The Lancet Psychiatry, 7(4), e19 (2020).

23. C. W. Rudolph, H. Zacher, The COVID-19 generation: A cautionary note, Work, Ageing and Retirement, waaa009 (2020).

24. S. K. Powers, E. T. Howley, Exercise physiology: Theory and application to fitness and performance, McGraw-Hill, New York (2001).

25. A. S. Abdulamir, R. R. Hafidh, The Possible Immunological Pathways for the Variable Immunopathogenesis of COVID--19 Infections among Healthy Adults, Elderly and Children, Electronic Journal of General Medicine, 17(4) (2020).

26. L. Duan, G. Zhu, Psychological interventions for people affected by the COVID-19 epidemic, The Lancet Psychiatry, 7(4), 300-302 (2020).

27. D. Jiménez-Pavón, A. Carbonell-Baeza, C. J. Lavie, Physical exercise as therapy to fight against the mental and physical consequences of COVID-19 quarantine: Special focus in older people, Progress in cardiovascular diseases (2020).

28. K. Muir, A. Powell, S. McDermott, They don't treat you like a virus: youth-friendly lessons from the Australian National Youth Mental Health Foundation, Health \& social care in the community, 20(2), 181-189 (2012). 